DOI: $10.22363 / 2312-9182-2018-22-1-38-53$

\title{
EMOTIONS OF JESUS
}

\author{
Anna Wierzbicka \\ Australian National University \\ Canberra, 0200, Australia
}

\begin{abstract}
In a book entitled The Sermon on the Mount: The modern Quest for its meaning, theologian Clarence Bauman (1985) discusses, inter alia, Jesus' teaching on "anger". The book opens with a chapter on Tolstoy: "Leo Tolstoy: The moral challenges of literal interpretation": "Christ's first commandment is "Do not be angry" (Matthew 5: 22-25). Tolstoy noted that the text had been tampered with by redactors. By the fifth century the word $\varepsilon \imath \kappa \eta$, meaning "needlessly" or "without cause," had been inserted into the initial unconditional statement: "Whosoever is angry with his brother without a cause...". But what did Jesus really teach about "anger"? The term used in Matthew's Gospel (5:22) is of course not the English word anger but the Greek word orgizomai - and the two don't mean the same. The term used by Tolstoy - the Russian word gnevat'sja - is different in meaning from both anger and orgizomai. But the word used by Jesus was neither English, nor Greek, nor Russian, but Aramaic. So what did that Aramaic word mean - and what did Jesus intend to say with it? Tolstoy's impulse to look for the "literal interpretation" is understandable, but as this chapter shows, the idea that we can pinpoint what Jesus meant with one word, from a particular language (be it Russian, English, Greek or Aramaic) is simplistic. The paper argues that in order to fully understand Jesus' teaching about "anger" in a precise and unbiased way, we need to go beyond single words of this or that language, and to try to articulate it through simple sentences couched in universal (i.e. universally-contestable) words. Furthermore, the paper shows that what applies to Jesus' teaching about emotions applies also to Jesus' "emotional practice". What did he feel when he saw someone doing something very bad, or someone to whom something very bad was happening? As the paper demonstrates, the "Natural Semantic Metalanguage" (NSM) developed by the author and colleagues allows us to replace crude formulations such as "Did Jesus feel angry?" or "What did Jesus teach about anger?" with questions which are far more fine-grained, and which enable us to reach far more fine-grained, and more meaningful answers.
\end{abstract}

Keywords: emotions, anger, Sermon on the Mount, Natural Semantic Metalanguage, translatability of emotion concepts

\section{INTRODUCTION AND BACKGROUND}

The subject of Jesus' emotions in the Gospels is of great interest to many people who want to know what Jesus was like, and there are many books and articles on the subject (cf. e.g. Law 1915, Elliott 2006, Voorwinde 2011). One question which often comes under discussion is this: was Jesus angry at times? And if so, how can his "anger" be reconciled with his teaching against "anger"'? These questions concerning Jesus' "anger" will be discussed in detail in section 2, and elaborated in relation to "curses" and "woes" in section 3. First, however, I will make some preliminary remarks on the semantics of emotions in general and Jesus' emotions in particular.

${ }^{1}$ For an earlier discussion of this teaching, see my 2001 book What Did Jesus Mean?, pp. 61-71. 
In addressing the question of Jesus' emotions in this paper, I am returning to a broader issue of the framework within which such questions can be meaningfully and fruitfully explored. In an earlier paper devoted to Jesus' emotions (Wierzbicka 2009) I discussed this broader issue in relation to Jesus' emotions in Gethsemane, as presented, above all, in Mark's Gospel (Mk 14: 33-34). Quoting the key lines in English (Revised Standard Version, RSV) and in Russian (in Averintsev's translation), I pointed out that the interpretation of Jesus' emotions in these two versions, English and Russian, was quite different.

English, $R S V$

33. And he took with him Peter and James and John, and began to be greatly distressed and troubled. 34. And he said to them, "My soul is very sorrowful, even to death, remain here, and watch". (Mark 14: 33-34)

\section{Russian (Averintsev 2007)}

33. ... I načal On čuvstvovat' užas i tomlenie, 34. i govorit im: "V smertnoj muke duša Moja; pobud'te zdes' i bodrstvujte".

As I pointed out in that earlier paper, the English words "distressed" and "troubled" are very different in meaning from the Russian words "užas" (usually glossed in English as "horror" or "terror") and "tomlenie" (roughly, "torment") — and all of those are different from the Greek words ekthambeisthai and ademonein in the original Greek of Mark's Gospel. Further, I argued that to reach a better understanding of what Jesus felt, we need to go beyond language-specific emotion terms, and try to understand the thoughts which gave rise to his feelings. In essence, I arrived at the following formula (I say "in essence" because a decade later, I think this formula can be somewhat improved, and I am adjusting it accordingly):

Jesus began to "ekthambesthai" and "ademonein" (Mk 14:33)

Jesus thought like this at that time:

"I know: something very bad will happen to me in a short time

I can't not think like this now: "I don't want it to happen"

I didn't know before that it would be like this"

when he thought like this, he felt something very bad, as someone can feel when they think like this for some time

The main idea behind this representation is that feelings can best be described with reference to thoughts, and also, that thoughts can best be identified in simple and universal human concepts, in accordance with the semantic methodology known as NSM (from Natural Semantic Metalanguage) (Wierzbicka 1996; Goddard 2011 [1998]; Goddard and Wierzbicka eds. 2002; Peeters (ed.) 2006; Goddard (ed.)).

As many studies in the NSM framework over many years have demonstrated, it is possible to describe human emotions without relying on the language-specific emotion terms of any particular language (be it English, Russian, Greek, or any other) if we base our description of different kinds of emotions on the analysis of prototypical thoughts which give rise to them, and if these thoughts are formulated in universal human concepts, as it is done in the NSM framework. Since this methodology is well known, here I will only offer the briefest possible explanation. 
The Natural Semantic Metalanguage (NSM) is a mini-language which corresponds to the intersection - the common core - of all languages. This intersection of all languages has been identified empirically, through extensive cross-linguistic studies undertaken by many scholars over many years (see e.g., Goddard and Wierzbicka eds. 1994, 2002). Describing languages and cultures in NSM, and through NSM, means describing them in terms of simple and universal human concepts, which can be found as words (or word-like elements) in all languages (see Table 1). This applies to emotions as much as to any other domain: by using NSM, we can explore human emotions from a universal point of view, independent of any particular languages and cultures. (For references, see the NSM homepage: <www.griffith.edu.au/humanities-languages/schoolhumanitieslanguages-social-science/research/natural-semantic-metalanguage-homepage> [short URL bit.ly/1XUoRRV]).

Table 1

Semantic primes (English exponents) (Goddard \& Wierzbicka 2014)

\begin{tabular}{|c|c|}
\hline I, YOU, SOMEONE, SOMETHING THING, PEOPLE, BODY & substantives \\
\hline KINDS, PARTS & relational substantives \\
\hline THIS, THE SAME, OTHER ELSE & determiners \\
\hline ONE, TWO, SOME, ALL, MUCH MANY, LITTLE FEW & quantifiers \\
\hline GOOD, BAD & evaluators \\
\hline BIG, SMALL & descriptors \\
\hline KNOW, THINK, WANT, DON'T WANT, FEEL, SEE, HEAR & mental predicates \\
\hline SAY, WORDS, TRUE & speech \\
\hline DO, HAPPEN, MOVE & actions, events, movement \\
\hline BE (SOMEWHERE), THERE IS, BE (SOMEONE/SOMETHING) & location, existence, specification \\
\hline (IS) MINE & possession \\
\hline LIVE, DIE & life and death \\
\hline $\begin{array}{l}\text { WHEN TIME, NOW, BEFORE, AFTER, A LONG TIME, A SHORT TIME, } \\
\text { FOR SOME TIME, MOMENT }\end{array}$ & time \\
\hline $\begin{array}{l}\text { WHERE PLACE, HERE, ABOVE, BELOW, FAR, NEAR, SIDE, INSIDE, } \\
\text { TOUCH }\end{array}$ & place \\
\hline NOT, MAYBE, CAN, BECAUSE, IF & logical concepts \\
\hline VERY, MORE & augmentor, intensifier \\
\hline LIKE & similarity \\
\hline
\end{tabular}

Using this set of universal human concepts (semantic primes) as their bedrock, NSM researchers have also developed, in recent years, a new descriptive tool known as "Minimal Language" (see e.g. Goddard ed. 2017; Wierzbicka 2017 and Forthcoming). Usually, the term "Minimal Language" is used for a somewhat enlarged version of the NSM, with some additional vocabulary allowed for a particular purpose. For example, in my book What Christians Believe: The Story of God and People in Minimal English (Forthcoming), where the "Christian story" is presented in a narrative form, I permit myself to use words like "shepherd", "bread" and "wine", which are not universal but which are integral to the theme.

No such additional vocabulary is needed for the domain of emotions, which is discussed in the present paper, so the analyses presented here do not go beyond "classical 
NSM". On the other hand, the label "Minimal Language" can also be used as an umbrella term, covering both the enlarged versions of NSM (such as Minimal English and Minimal Polish) and the NSM itself (as a limiting case). It is in this second sense that I will be using the term "Minimal Language" in the present paper.

\section{THE "ANGER" OF JESUS}

\subsection{Jesus" teaching on "anger"}

In the Sermon on the Mount Jesus says (Mt. 5:27, RSV): "I say to you that everyone who is angry [orgizomenos] with his brother shall be liable to judgment (...) and whoever says 'You fool!' shall be liable to the hell of fire." (In the Revised Standard Version, this section has the heading "Teaching about anger".)

Yet when Jesus confronts the Pharisees (in Mt. 23: 13-33), he doesn't hesitate to say to them: "You blind fools" (v. 17, RSV) and even "You serpents, you brood of vipers, how are you to escape being sentenced to hell?" (v. 33). Some commentators, used to different emotional styles, seem discomfited by such an outburst. Thus, speaking of the "anger" and "indignation" that Jesus showed (according to Mark 9: 38) when his disciples tried to prevent parents from bringing little children to him (so that he could bless them), Voorwinde (2011: 106) asks: "Could a reference to Jesus' indignation impugn his sinlessness?" This would explain, he suggests, the "omission" of such references in Luke and Matthew's accounts of the same incident.

Rethinking through Minimal Language the passages where Jesus teaches about "anger", and also those where he appears to show "anger" himself, we can resolve the conundrum, because Minimal Language allows a more fine-grained analysis of emotions than a coarse-grained one relying on categories like "anger" and "indignation".

The first point to note is that words like anger do not match in meaning across languages, and that there is no point in thinking about Jesus solely through the prism of the English word anger, rather than the German word Wut, the Greek word orge, the Russian word serdit'sja, or the Pitjantjatjara word pika, each of which embodies a different concept. (Cf. e.g. Durst 2001; Goddard 1991; Wierzbicka 1992, 1999, 2014.) Each such concept represents a culture-specific configuration of several components amalgamated into one whole.

Different language-specific "anger-like" words can include in their meaning different, though overlapping, combinations of such components (amalgamated into one whole). I am not going to try here to explicate the English word anger, or any of its closest counterparts in other languages (see, e.g., Wierzbicka 1998). I will note, however, that the meaning of such words often includes components like the following ones (for the sake of simplicity, to refer to the "angry" person I will use the word "he").

he felt something (very) bad

he felt something (very) bad towards someone he thought like this about someone: "this person is doing something (very) bad" he wanted to do something bad to this someone he wanted bad things to happen to this someone 
If we use Minimal Language, we don't have to rely, in our interpretation of Jesus' emotions, on complex language-specific emotion terms; rather, we can talk about them in a language-independent way, using individual semantic components expressible in universal words. For example, we can ask about a particular episode in the Gospels in which Jesus appeared to be "angry":

Did Jesus feel something bad?

Did he feel something bad towards someone?

Did he want to do something bad to someone?

Did he want something bad to happen to this someone?

Was he saying to someone: "you are doing something bad"?

Was he saying to someone: "you are doing something very bad"?

Was he saying to someone: "I don't want you to do this"?

To illustrate how the use of such components can help us to achieve a more finegrained interpretation of Jesus' emotions, I will discuss four scenes where Jesus appeared to be "angry".

\subsection{Did Jesus feel something bad towards the disciples?}

And they were bringing children to him, that he might touch them, and the disciples rebuked them. But when Jesus saw it he was indignant [heganaktesen], and said to them: "Let the children come to me, do not hinder them; for to such belongs the kingdom of God". (Mk. 10: 13-14, RSV)

The verb aganakteo is glossed by the Greek-English Dictionary of the New Testament as 'be indignant or angry', but this is not a very accurate statement of this verb's meaning (if only because indignant doesn't mean the same as angry). Using Minimal Language, we can portray Jesus' attitude more precisely (as well as more cross-translatably):

[A] I think like this now: You are doing something bad.

I feel something bad because of this.

I don't want you to do it.

This formula is quite consistent with Jesus' words, and there is no need to add to it a further component along the lines of: "he felt something bad towards them at that moment".

\subsection{Did Jesus feel something bad towards Simon Peter?}

In Matthew's chapter 16, Jesus asks the Apostles: "Who do men say the Son of Man is?" and when Peter replies: "You are the Christ, the Son of the living God", Jesus entrusts him the "keys of the kingdom of God":

Blessed are you, Simon Bar-Jona! (...) And I tell you, you are Peter, and on this rock I will build my church, (...), and I will give you the keys of the kingdom of heaven. (Mt. 16: $17-19, \mathrm{RSV})$ 
In the passage that follows, however, in which he foretells his suffering and death, Jesus apparently gets very "angry" at Peter:

And Peter took him and began to rebuke him, saying: "God forbid, Lord! This shall never happen to you". But he turned and said to Peter: "Get behind me, Satan! You are a hindrance to me; for you are not on the side of God, but of men". (Mt. 16: 22-23)

Here, Jesus' attitude to Peter can be portrayed as follows:

[B] I think like this now: When you say this, you are doing something very bad to me. I feel something very bad because of this.

I don't want you to say things like this.

The difference between "you are doing something bad" (in hindering the children from coming to Jesus) and "you are doing something bad to me" (in tempting Jesus to abandon his God-given mission) is significant, and may suggest to readers of the Gospels a stronger feeling. There is no reason, however, to assume that at that moment, Jesus felt something bad towards Peter, let alone that he wanted to do something bad to Peter. Jesus' reaction here is different from that in the previous vignette, but this difference appears to be sufficiently accounted for by saying "bad" in the first case and "very bad" (as well as including the phrase "to me") in the second.

\subsection{Did Jesus feel something bad towards the scribes and the Pharisees?}

When confronting the scribes and Pharisees in Jerusalem and pointing out their hypocrisy, Jesus uses strong language which has often been interpreted in various commentaries in terms of "anger", "indignation", or "wrath". Voorwinde (2011: 78) speaks here of "anger", and Law (1915:97), of "indignant wrath").

Woe to you, scribes and Pharisees, hypocrites! because you shut the kingdom of heaven against men; for you neither enter yourselves, nor allow those would enter to go in. (...) You blind guides, straining out a gnat and swallowing a camel! (...) You serpents, you brood of vipers, how are you to escape being sentenced to hell?

To fully understand Jesus' speech, we need not only to grasp his message but also to know something about Jewish "cultural scripts" (cf. Wierzbicka 2004), to which I will turn very shortly. For the moment, however, let me try to model Jesus' message to his interlocutors:

[C] I think like this now: You are doing something very bad.

I feel something very bad because of this.

I don't want you to do things like this.

If one said to someone "You hypocrite!" in a modern English-speaking society such as Australia, this would certainly be understood as conveying the message "I feel something bad (indeed, very bad) towards you". But speech culture in first-century Palestine was different. In the context of that culture (in which Jesus could say to one of his closest friends: "Satan!"), Jesus' utterance conveys the message "You are doing something very bad, I feel something very bad because of this, I don't want you to do things like this", and not: "I feel something very bad towards you". 


\subsection{Did Jesus feel something bad towards the sellers and money-changers in the Temple?}

...Jesus went up to Jerusalem. In the temple he found those who were selling oxen and sheep and pigeons, and the money-changers at their business. And making a whip of cords, he drove them all, with the sheep and the oxen, out of the temple; and he poured out the coins of the money-changers and overturned their tables. And he told those who sold the pigeons, "Take these things away; you shall not make my Father's house a house of trade". His disciples remembered that it was written, "Zeal for thy house will consume me".

Arguably, here, Jesus' attitude can be portrayed as follows:

[D] I think like this now:

You are doing something very bad,

something very bad is happening in this place because of this.

I feel something very bad because of this.

I want to do something because of this.

In this scene, unlike in the case of the scribes and the Pharisees, it is not the actions of the sellers and the money-changers as such that make Jesus "feel something very bad", but the resulting state of affairs: the degradation of the Temple ("his Father's house"). This is highlighted in the Gospel by the quotation from Psalm 69 ("Zeal for thy house will consume me").

As I see it, there is no need here to posit bad feelings towards the sellers of oxen and sheep, or the money-changers, on Jesus' part. Rather, he feels very strongly about what is happening to the Temple, and wants to do something because of this. Hence the overturning of the money-changers' tables, and the driving of the sellers, together with their oxen and sheep, out of the temple.

Is there any evidence suggesting that Jesus felt something bad towards those moneychangers and those sellers, and that he wanted to do something bad to them? As I read John's account of this event (as well as those of Matthew, Mark and Luke), I do not find any such evidence. Jesus' attention was on the degradation of the Temple, not on the people who were responsible for it, and on his strongly felt need to restore the Temple's dignity.

\subsection{Comparing the four vignettes with Jesus' teaching}

To compare these four vignettes with Jesus' teaching about "anger" (mentioned briefly in section 2.1), we need to understand that teaching, too, in terms of precise and cross-translatable semantic components. Thus, in the Sermon on the Mount (Mt. 5: 24) we read:

You have heard that it was said to the men of old, 'You shall not kill; and whosoever kills shall be liable to judgment.' But I say to you that everyone who is angry with his brother shall be liable to judgment.

As one commentator (Crenshaw 1993: 533, in The Oxford Companion to the Bible) puts it, "Jesus broadened the prohibition of murder to include anger (Matt. 5. 21-22)". This is consistent with the following formulation:

It is very bad if someone wants to do something very bad to someone else. 
But what about the verse in the same section that immediately follows: "....and whoever says, 'You fool!' shall be liable to hell fire" (Mt. 5: 22)? What was wrong, from Jesus' point of view, with saying to someone "You fool!'? Given the context, which contrasts a person's outer behaviour with their inner disposition ("the heart"), it is likely that he was referring here to the speaker's feelings, rather than his or her words.

The most likely hypothesis seems to be that these words represent a warning against giving in to bad feelings towards another person. The strongest argument in favour of this interpretation is Jesus" overall emphasis on "forgiveness", that is, essentially, on the need to let go of any bad feelings that one may have towards someone because this person has done something bad to us.

As any readers of the Gospels will know, Jesus' listeners were repeatedly urged to "forgive" - that is, essentially, not to feel something bad towards someone else when such a feeling might seem to be more justifiable than in any other circumstances. This implies that they were strongly encouraged to try not to have bad feelings towards other people under any circumstances. (Or, as my "Story of God and People" puts it, "it is bad for you if you feel something bad towards someone else").

In his teaching about the "defilement" (Mk 7:14, Mt 15:10), Jesus says that the "defilement" comes from within; from "evil thoughts", and this includes "murder". ("For from within, out of the heart of men, proceed evil thoughts, adulteries, fornications, murder, thefts (...)", Mark 7:6.) What exactly does it mean, that murder comes from the heart? The clearest semantic component is the warning against thinking about someone: "I want to do something bad to this someone"; but since the Greek word kardia ('heart') implies both thoughts and feelings, it seems likely that Jesus is also warning here against "feeling something bad towards someone".

Of course the clearest warning against such feelings comes from the teaching about "forgiveness", that is, roughly, about "not wanting to feel something bad towards someone for some time". But since people are told to forgive someone who has sinned against them "seven times a day" (Lk 17: 3) (and according to Matthew (8: 21), seventy-seven), evidently Jesus is warning his listeners against even short-term bad feelings towards their offenders.

Jesus' teaching about "forgiveness" and "turning the other cheek" can be misunderstood (along the lines of the prayer "Gentle Jesus, meek and mild," mocked by Chesterton (1908: 118). It is good to acknowledge, therefore, that Jesus did express some forceful messages, such as the following ones:

You are doing something very bad.

I feel something very bad because of this.

I don't want you to do it.

I want to do something because of this.

It is also good to be able to distinguish such messages, with precision, from messages like the following ones:

I want to do something (very) bad to you.

I want something (very) bad to happen to you.

I feel something (very) bad towards you. 
In the light of the Gospels as a whole, it seems clear that Jesus was warning people, above all, against "feeling something very bad towards someone". Undoubtedly, he was also enjoining people not to want to do anything bad to anyone, and not to want anything bad to happen to anyone; but since such "wants" often result from bad feelings towards people, he saw bad feelings towards someone or some people as dangerous and damaging, too.

As demonstrated, for example, in my book Emotions Across Languages and Cultures and other NSM-based work (see, e.g. Goddard 2014; Goddard and Ye eds. 2016; Ye 2001), a combination of components based on the universal prime FEEL (such as "to feel something (very) bad" and "to feel something (very) bad towards someone" with detailed cognitive scenarios based on the universal prime think give us truly fine-grained description of emotions and emotional attitudes. Minimal English (or any other NSMbased Minimal Language) helps us to clarify such differences in a precise, transparent, and language-independent way.

\section{3. "CURSES" AND "WOES"}

Jesus' teaching about "not wanting bad things to happen to anyone", with a special focus on one's enemies and persecutors, is quite explicit:

...bless those who curse you, pray for those who abuse you. (Lk 6: 28)

In Minimal Language, this can be formulated as follows:

[E] If someone does something bad to you, it will be bad if you want something bad to happen to this someone because of this; it will be good if you want something good to happen to this someone.

Arguably, such sayings in both Matthew's and Luke's Gospels suggest more general formulations:

[F] It is bad if you want something bad to happen to someone else.

It is good if you want good things to happen to other people.

This raises some interesting questions about the meaning of the "woes" (In New Testament Greek, ouai) in Jesus' speech, such as those that we have already seen addressed to the Pharisees: "Woe to you, scribes and Pharisees, hypocrites!"

The wild and comical hyperbole of "straining out the gnat and swallowing the camel" should be a warning to the modern reader not to try to interpret Jesus' speech according to modern (and especially Anglo) cultural norms such as moderation, precision, consistency, "rationality", or emotional restraint (see Wierzbicka 2006). More generally, such hyperboles underscore the potential for cross-cultural misunderstandings between the Gospel writers and the modern readers of the Gospels. The point is that in trying to understand Jesus' emotions through emotion terms in our own languages, we have to beware of interpreting them in accordance with the cultural scrips of other societies (Wierzbicka 1994, 2006). The scripts of Jesus' culture were very different. This applies in particular to "scripts" for expressing emotions — as documented in James Matisoff's splendid book Blessings, Curses, Hopes and Fears: Psychoostensive expressions in Yiddish (2000). Expressing "bitterness" through "curses" is one such Jewish 
cultural script, as illustrated in the following passage from an English translator's Introduction to a volume of Sholem Aleichem, quoted by Matisoff:

There are as many types of curses as there are people cursing, but the hardest to explain is the mother cursing her child. The child may be crying because he is hungry. The mother bursts out 'Eat, eat, eat. All you want to do is eat. May the worms eat you. May the earth open up and swallow you alive'. This mother loves her child, she is only pouring out the bitterness that's in her heart in the only way she knows. But in translation she sounds like a monster. (Butwin 1958: 9).

As discussed in my paper, "Jewish cultural scripts and the interpretation of the Bible" (2004), such cultural scripts, characteristic of Yiddish, have their roots in biblical culture. "Jewish woes" are not exactly the same as "Jewish curses", although the two are close in meaning. But a "curse" says (literally), so to speak: "I want something very bad to happen to you", whereas "woes" (which can be addressed to oneself, as in one Paul's letters in the New Testament (1 Cor 9:16) or in Jeremiah in the Old Testament (6:4), say "it will be good if something very bad happens to this person". In their original cultural context, both these speech genres are expected to be interpreted as "I say this because I feel something very bad, I want someone to know what I feel".

Thus, when Jesus seemingly threatens his opponents the Pharisees with hellfire (using at the same time a characteristically Jewish rhetorical question, cf. Rosten 1968), he is indeed expressing a "bad feeling" ("I feel something very bad"), but not "ill will" ("I want something bad to happen to you"). To think that he wanted something bad to happen to those Pharisees would be a case of cross-cultural misunderstanding. The impression that he was feeling something bad "towards them" is sufficiently accounted for by the combination of components "you are doing something very bad", "I feel something very bad because of this".

When modern readers come across utterances such as "Woe to you scribes and Pharisees, hypocrites", they need commentaries of two kinds: semantic, and cultural, and both such commentaries can be provided with the help of Minimal English. The strictly semantic question is: what does "woe to you" actually say (in its "dictum", see Goddard and Wierzbicka 2014), and the cultural one, how were those who shared Jesus' speech culture expected to interpret it? Using Minimal English, we can answer these two questions as follows:

[G] [I say:] it will be good if something very bad happens to you [or: me; or, someone else] I say this because I want you to know what I feel at this moment

Such "woes" are related to the Jewish ritualized "curse", or klole (Hebrew): "petitive expressions that [on the face of it, A.W.] call down misfortune, disease, or death on their intended victims" (Matisoff 2000: 72). As Matisoff further points out, "Needless to say, the malo-petitioners would often be appalled if the dire eventuality actually came to pass" (Matisoff 2000: 72). What Matisoff is saying here is that it is part of Jewish culture to say that one wants something bad to happen to someone in order to express what one feels at a particular moment.

The Greek-English Dictionary of the New Testament glosses the Greek word ouai!, rendered traditionally in English translation as "woe to you", as "how horrible it will be!" 
But this sounds like a prediction or a lament rather than a "wish" of any kind. Taking into account Matisoff's work on ritualized Jewish "curses" and related speech acts, and using Minimal English, we can try to get closer to the real meaning of such exclamatory utterances with formula [G], bearing in mind that such "curses" can be directed at the speaker him- or herself, or at some other person or place, as in Jesus' "woes" directed as the "unrepentant cities" in his homeland Galilee:

Woe to you, Chorazin! Woe to you, Bethsaida! for if the mighty works done in you had been done in Tyre and Sidon, they would have repented long ago in sackcloth and ashes. (Mt 11:21)

\section{THE CHALLENGE OF THE GREEK EMOTION TERM "TETĀRAKTAI"}

In this paper, I have argued that if we want to understand Jesus' emotions, we need to go beyond the emotion terms of any particular language and try to understand, on the basis of his words and the context, his underlying thoughts. Before closing, I will illustrate this general tenet with the challenge of the Greek word tetāraktai, used three times in John's Gospel - a term which the NRSV renders with the phrase "troubled", and the Russian synodal translation, with the words "voskorbet' (duxom)" (roughly, "to grieve") and "vozmutit'sja" (roughly, "perturbed"). To show this, I will first adduce three relevant passages from the NRSV, and then, an extended comment from Benedict XVI, in which the Pope tries to explain, in discursive prose, what Jesus felt on those three occasions.

\section{Speaking about his death}

Jesus answered and said: The hour has come for the Son of Man to be glorified. Very truly, I tell you, unless a grain of wheat falls into the earth and dies, it remains just a single grain; but if it dies, it bears much fruit. (...)

Now my soul is troubled. [Duša moja teper' vozmutilas'.] (John 12:27)

2. Talking to Mary, the sister of Lazarus

"Lord, if you had been here, my brother would not have died!" When Jesus saw her weeping, he was greatly disturbed in spirit and deeply moved [voskorbel duxom i vozmutilsja.] He said, "Where have you laid him?" (John 11:33)

3. At the Last Supper, speaking of Judas' betrayal

After saying this, Jesus was troubled in spirit [vozmutilsja duxom], and declared, 'Very truly, I tell you, one of you will betray me." (John 13:21)

Speaking of Mark's and Luke's accounts of Jesus' emotions in Gethsemane, just before his arrest, Benedict XVI writes:

We may distinguish three elements in this prayer of Jesus. First there is the primordial experience of fear, quaking in the face of the power of death, terror before the abyss of nothingness that makes him tremble to the point that, in Luke's account, his sweat falls to the ground like drops of blood (cf. 22:44). In the equivalent passage in Saint John's Gospel (12:27), this horror is expressed, as in the Synoptics, in terms reminiscent of Psalm 43:5, but using a word that emphasizes the dark depths of Jesus' fear: tetáraktai - it is the same verb, tarássein, that John uses to describe Jesus' deep emotion at the tomb of Lazarus (cf. 11:33) as well as his inner turmoil at the prophecy of Judas' betrayal in the Upper Room (cf. 13:21). 
In this way John is clearly indicating the primordial fear of created nature in the face of imminent death, and yet there is more: the particular horror felt by him who is Life itself before the abyss of the full power of destruction, evil, and enmity with God that is now unleashed upon him, that he now takes directly upon himself, or rather into himself, to the point that he is "made to be sin" (cf. 2 Cor 5:21).

The Greek-English Dictionary of the New Testament (1971) glosses the word tarassein as "trouble, disturb, upset; terrify, frighten; stir up (of water)". These glosses suggest a feeling that is both "very bad" and "sudden" (as in "stir up"), and they are helpful; but they do not try to capture the invariant semantic component of the word. Nor do they enable us to find a plausible common core of Jesus' experiences described with this word in John's Gospel. Using Minimal English, I would tentatively propose the following characterization of the common core:

$[\mathrm{H}]$ Jesus felt something very bad at that moment.

People can think about it like this:

He thought like this: "very bad things can happen to people, people can do very bad things.

When he thought like this, he felt something very bad.

This formula doesn't affirm that we know Jesus' exact thoughts on those three occasions, but it invites the reader to imagine what one would feel if one thought like this. Since Benedict XVI links the experience in question with thoughts about death ("Each time, it is a question of Jesus' encounter with the power of death", p. 163), we might consider adding "people die" after "very bad things can happen to people". I have refrained from doing so, however, because I don't think this would fit Jesus' words relating to Judas' betrayal. In fact, in the case of Lazarus, too, it is not clear whether the presumed thought "very bad things happen to people" would apply to Lazarus himself (who died) or to his sister Mary (who had lost her brother). Furthermore, if we refrain from including the component "people die" in the explication, we leave the possibility open that Judas' betrayal is viewed not only as "something very bad that Judas did", but also, as "something very bad that happened to Judas"; and this would seem to be consistent with the tenor of Jesus' words. (I will note in this context that Alexander Men, in his book The Son of Man, describes Jesus' feelings in the Lazarus episode with the untranslatable Russian word "volnenie", as "glubokoe volnenie", "deep volnenie").

The exact phrasing of formula $[\mathrm{H}]$ is of course open to discussion. I should add that this formula is not necessarily an accurate semantic explication of the Greek word tetáraktai (tarássein) as such. Rather, the aim of this formula is to provide a plausible characterization of Jesus' emotions which one of those who were with Jesus at the time (John) sought to approximate with this Greek word. What seems to me to be really conclusively established is the inadequacy of complex and language-specific terms: "horror", "fear", "troubled", "turmoil" and "užas". Terms like this are bound, to some extent, to distort Jesus' emotions. In different translations of the Gospels, such distortions are no doubt unavoidable. They can, however, be avoided in the commentaries and explanatory notes, if we base our interpretation of Jesus' emotions on simple and cross-translatable words such as "think" and "feel", "good" and "bad", "do" and "happen", that is, on what appear to be fundamental and universal human concepts. 


\section{CONCLUDING REMARKS}

To conclude, the Gospels tell us a great deal about Jesus' emotions, but what they are telling us cannot be fully captured with emotion terms of any particular language (e.g. English, Russian, or Greek). We can get much closer to an understanding of Jesus' emotions if we think about them with the help of simple and cross-translatable words such as "feel", "think", "good" and "bad", and cross-translatable phrases such as "feel something bad towards someone", "feel something good towards someone". Using such words and phrases we can ask clear questions such as 1 and 2:

1. Did Jesus sometimes feel something very bad?

2. Did Jesus sometimes feel something very bad towards someone?

We can also give clear answers to these questions: Yes to question 1, and No to question 2. These answers are entirely consistent with Jesus' teaching preserved in the "Sermon on the Mount" and elsewhere in the Gospels. Jesus never taught that it was bad "to feel something very bad", but he did teach (though not in these words) that it was bad "to feel something very bad (and even something bad) towards someone".

What about question 3, then: Did Jesus teach (in some form) that it is bad to say to someone: "you are doing something very bad, I feel something very bad because of this"? Here, too, we can provide a clear and unequivocal answer with Minimal Language: No, he didn't teach that. On the other hand, he did teach (not in this form) that it is bad to say to someone: "You are doing something very bad, I feel something very bad towards you because of this". To see how important such distinctions are, it is enough to recall a commentator's question quoted earlier: "Could a reference to Jesus' indignation impugn his sinlessness?"

In a sense, the question is absurd, but it is also instructive. It is absurd because for Christians (and by no means only for Christians), Jesus shows us what a perfect human life looks like: people are "sinful" to the extent to which they are not like Jesus. "What is sin?" (Čto značit grex?), asks Mary Magdalene in Pasternak's poem which bears her name; and for Christians, the answer must be: being not like Jesus — not so much in one's actions (which depend, to a very large extent, on one's circumstances) as in one's thoughts, wants and feelings (which are more subject to one's will). But the commentator's wistful question is also instructive, because it shows how easy it is to be confused about what Jesus was really like.

I submit that an important part of the answer to the question of what Jesus was like lies in the distinction between, on the one hand, "feeling something very bad" and, on the other, "feeling something very bad towards someone" - a distinction which Minimal Language allows us to make clearly, precisely, and "cross-translatably".

(C) Anna Wierzbicka, 2018

\section{REFERENCES}

Averintsev, Sergej (2007). Sobranie sočinenij [Collected works]. Kiev: Dux i Litera.

Butwin, Frances (1958). Translator's introduction to Sholom Aleichem [Rabinowitz], The Old Country. London: Andre Deutsch.

Chesterton, G.K. (1908). The Everlasting Man. Radford, VA: Wilder Publications. 
Crenshaw, James L. (1993). Murder. In Bruce M. Metzger and Michael D. Coogan, The Oxford Companion to the Bible (532-533). New York; Oxford: Oxford University Press.

Durst, Uwe. 2001. Why Germans don't feel “anger”. In Jean Harkins and Anna Wierzbicka (eds.), Emotions in Cross-linguistic Perspective, 115-148. Berlin: Mouton de Gruyter.

Elliott, Bianca (2006). The Emotions of Jesus. Martinsville, IN: Airleaf.

Goddard, Cliff (1991). Anger in the Western Desert: A case study in the cross-cultural semantics of emotion. Man 26 (2): 265-279.

Goddard, Cliff (2014). Interjections and emotions (with special reference to "surprise" and "disgust"). Emotion Review 6 (1): 53-63.

Goddard, Cliff and Anna Wierzbicka (2014). Words and Meanings: Lexical Semantics Across Domains, Languages, and Cultures. Oxford: Oxford University Press.

Goddard, Cliff and Anna Wierzbicka (Eds.) (1994). Semantic and lexical universals: Theory and empirical findings. Amsterdam: John Benjamins.

Goddard, Cliff and Anna Wierzbicka (Eds.) (2002). Meaning and universal grammar: Theory and empirical findings (Vols. 1-2). Amsterdam: John Benjamins.

Goddard, Cliff and Zhengdao Ye (Eds.) (2016). "Happiness" and "Pain" across Languages and Cultures. Amsterdam: John Benjamins.

Goddard, Cliff (Ed.) (2017). Minimal English for a Global World: Improved Communication in Fewer Words. Palgrave.

Greek-English Dictionary of the New Testament (1971). London: United Bible Societies.

Law, Robert (1915). The Emotions of Jesus. Edinburgh: T \& T Clark.

Matisoff, James (2000). Blessings, Curses, Hopes and Fears: Psychoostensive expressions in Yiddish. Stanford, CA: Stanford University Press.

Rosten, Leo (1968). The Joys of Yiddish. New York. McGraw-Hill.

Voorwinde, Stephen (2011). Jesus' Emotions in the Gospels. London: T\&T Clark.

Wierzbicka, Anna (1992). Semantics, Culture and Cognition: Universal human concepts in culturespecific configurations. New York: Oxford University Press.

Wierzbicka, Anna (1999). Emotions Across Languages and Cultures: Diversity and Universals. Cambridge: Cambridge University Press.

Wierzbicka, Anna (2004). Jewish cultural scripts and the interpretation of the Bible. Journal of Pragmatics. 36(3), 575-599.

Wierzbicka, Anna (2009). Language and metalanguage: Key issues in emotion research. Emotion Review. 1 (1) 3-14.

Wierzbicka, Anna (2014). Imprisoned in English: The hazards of English as a default language. New York: Oxford University Press.

Wierzbicka, Anna (2017). W co wierza chrześcijanie? Opowieść o Bogu i o ludziach [What Christians Believe: The Story of God and People]. Cracow: Znak.

Wierzbicka, Anna (Forthcoming). What Christians Believe: The Story of God and People. New York: Oxford University Press.

Ye, Zhengdao (2001). An inquiry into sadness in Chinese. In Jean Harkins and Anna Wierzbicka (eds.), Emotions in Cross-linguistic Perspective, 359-404. Berlin: Mouton de Gruyter.

\section{Article history:}

Received: 09 August 2017

Revised: 12 September 2017

Accepted: 20 September 2017 


\title{
For citation:
}

Wierzbicka, Anna (2018). Emotions of Jesus. Russian Journal of Linguistics, 22 (1), 38-53. doi 10.22363/2312-9182-2018-22-1-38-53.

\section{Bionote:}

ANNA WIERZBICKA is a Professor in the Linguistics Program, School of Languages, Literature and Linguistics, Australian National University. Her work spans a number of disciplines, including anthropology, psychology, cognitive science, philosophy and religious studies as well as linguistics, and has been published in many journals across all these disciplines. She has published over twenty books and edited or co-edited several others. Her latest book is What Christians Believe: The story of God and people published in Cracow, Poland in 2017 by Znak. Professor Wierzbicka is a Fellow of the Australian Academy of the Humanities, the Australian Academy of Social Sciences, and of the Russian Academy of Sciences, and the Polish Academy of Arts and Sciences. She is the winner of the International Dobrushin Prize for 2010 and of the Polish Science Foundation's 2010 prize for the humanities and social sciences. Contact information: anna.wierzbicka@anu.edu.au

\section{DOI: $10.22363 / 2312-9182-2018-22-1-38-53$}

\section{ЭМОЦИИ ИИСУСА ХРИСТА}

\author{
Анна Вежбицкая \\ Австралийский Национальный Университет \\ Канберра, Австралийская столичная тер. 0200, Австралия
}

В книге The Sermon on the Mount: The modern Quest for its meaning (Нагорная проповедь: современная интерпретация ее значения) (1985) теолог Кларенс Бауман, помимо многого другого, касается вопроса об учении Христа о “гневе”. Книга начинается статьей, посвященной Толстому "Leo Tolstoy: The moral challenges of literal interpretation" (Лев Толстой: Моральные проблемы буквального толкования). Одна из заповедей Христа - Не гневайся (от Матфея 5: 22-25). Толстой заметил, что в процессе редактирования проповеди ее текст был искажен. К пятому столетию в первоначальное безусловное утверждение было вставлено слово єєкп, означающее «бесполезно» или «без причины»: «Всякий, гневающийся на брата своего без причины...». Но чему действительно учил Христос, говоря о «гневе»? Термин, использованный в Евангелие от Матфея (5:22), это было, разумеется, русское слово «гнев», и не английское слово «anger», а греческое слово orgizomai. Слово, употребленное Толстым - русское слово «гневаться» - отличается по значению и от английского anger, и от греческого orgizomai. Но Иисус использовал не английское, не греческое и не русское слово, а арамейское. Что означало это арамейское слово, и что же хотел сказать Иисус, употребляя его? Вполне понятно желание Толстого найти «буквальное толкование», но, как показано в данной статье, пытаться определить, что хотел сказать Иисус, одним словом из того или иного языка (будь то русский, английский, греческий или арамейский), - значило бы чрезмерно упростить проблему. В статье утверждается, что для того, чтобы полностью понять учение Христа о «гневе» точным и беспристрастным образом, нам нужно выйти за рамки отдельных слов того или иного языка и попытаться сформулировать простые предложения, используя универсальные слова, то есть слова, которые имеют точные эквиваленты во всех языках. Кроме того, в статье показано, что то, что относится к учению Христа об эмоциях, относится также и к «эмоциональной практике» Христа. Что он чувствовал, когда видел, что кто-то делает что-то очень плохое или когда с кем-то что-то очень плохое происходит? Естественный семантический метаязык, разработанный автором и коллегами, позволяет заменить грубые формулировки, такие как «Испытывал ли Иисус гнев?» или «Что говорил Христос о гневе?», более тонкими вопросами, позволяющими получить более точные и содержательные ответы.

Ключевые слова: эмочии, гнев, Нагорная проповедь, естественный семантический метаязык, переводимость эмочиональных кониептов 


\section{История статьи:}

Дата поступления в редакцию: 09 августа 2017

Дата принятия к печати: 20 сентября 2017

\section{Для цитирования:}

Wierzbicka, Anna (2018). Emotions of Jesus. Russian Journal of Linguistics, 22 (1), 38-53. doi 10.22363/2312-9182-2018-22-1-38-53.

\section{Сведения об авторе:}

АННА ВЕЖБИЦКАЯ - известный лингвист, профессор Института языка, литературы и лингвистики Австралийского национального университета. Помимо лингвистики, ее научные интересы охватывают целый ряд дисциплин, включая антропологию, психологию, философию и религиоведение. Она опубликовала более двадцати книг, среди которых - Semantics, Culture and Cognition: Universal Human Concepts in Culture-Specific Configurations (N.Y., London: Oxford University Press, 1992), Cross-Cultural Pragmatics: The Semantics of Human Interaction (Berlin: Mouton de Gruyter, 1991/2003), Emotions across Languages and Cultures: Diversity and Universality (Cambridge: Cambridge University Press, 1999), English: Meaning and Culture (Oxford: Oxford University Press, 2006), What Christians Believe: The Story of God and People (Cracow: Znak). Профессор Вежбицкая является членом Австралийской академии гуманитарных наук, Австралийской академии общественных наук, Российской академии наук, Польской академии знаний, лауреатом Международной премии имени Добрушина (2010 г.) и премии Польского научного фонда (2010 г.). Контактная информация: anna.wierzbicka@anu.edu.au 